\title{
Microscopy and Microanalysis of Hematite Precipitates from the Zinc Industry
}

\section{T.T. Chen and J.E. Dutrizac}

\section{CANMET, Natural Resources Canada, 555 Booth Street, Ottawa, Ontario K1A 0G1}

In commercial zinc operations, sphalerite $(\mathrm{Zn}, \mathrm{Fe}) \mathrm{S}$ concentrates are roasted in air to produce a $\mathrm{ZnO}$ rich calcine; the $\mathrm{Fe}$ in the sphalerite is converted mostly to $\mathrm{ZnFe}_{2} \mathrm{O}_{4}$. The calcine is treated in sulphuric acid media to dissolve the $\mathrm{Zn}$, but the associated Fe also dissolves. The solubilized $\mathrm{Fe}$ is commonly precipitated as a jarosite-type compound $\mathrm{KFe}_{3}\left(\mathrm{SO}_{4}\right)_{2}(\mathrm{OH})_{6}$ or hematite $\mathrm{Fe}_{2} \mathrm{O}_{3}$ [1,2]. In current industrial practice, both the jarosite and hematite residues are sent to disposal sites. Although the jarosite process is more commonly used, jarosite precipitates are voluminous and require an extensive containment area [3]. The hematite process is more costly, but produces a compact, more stable material for disposal; furthermore, hematite precipitates have some market potential [4]. The hematite precipitates commonly contain 0.3-1.0 \% Zn, 5-10\% $\mathrm{SO}_{4}$ and 3-6 \% $\mathrm{H}_{2} \mathrm{O}$, impurities that presently restrict the use of the hematite residues. Consequently, a study was carried out, using multiple analytical techniques, to determine the compositions, microstructures and impurity forms of the hematite precipitates. The overall objective was to enhance the utilization of the hematite precipitates, thereby lessening the environmental impact of iron residue disposal.

In addition to the commercial hematite residues, a synthetic hematite precipitate prepared under conditions simulating those of the industrial process, but without the presence of $\mathrm{Zn}$, was also studied. Prior to analysis, all the samples were subjected to extensive water-washing, and were then air dried at $110^{\circ} \mathrm{C}$ for $24 \mathrm{~h}$. Various XRD, SEM/EDX and EPMA analyses were carried out; sulphide sulphur was distinguished from sulphate sulphur by X-ray crystal spectrometry on the EPMA. Complementary TGA-DTA-FTIR analyses were carried in a helium atmosphere, and the evolved gases were analyzed.

The synthetic hematite precipitate occurs as 1-10 $\mu \mathrm{m}$ spheroids, agglomerates or hollow spheroids. Most of these particles consist of radial crystallites, and have large surface areas, implying a high potential for adsorbing soluble species. The SEM study showed that the sample consists of only hematite; the hematite XRD lines are sharp, implying well crystallized $\mathrm{Fe}_{2} \mathrm{O}_{3}$. Detailed EPMA of the hematite particles gives: $65.2 \% \mathrm{Fe}$ and $4.7 \% \mathrm{SO}_{4}$, with $2.3 \% \mathrm{H}_{2} \mathrm{O}_{\text {calc }}$. The analysis is identical to the bulk composition of the precipitate. The FTIR analysis shows the separate evolution of $\mathrm{H}_{2} \mathrm{O}$ and $\mathrm{SO}_{2}$, implying that the gas evolution reaction is not the decomposition of $\mathrm{H}_{2} \mathrm{SO}_{4}$, as the decomposition of acid would result in the simultaneous release of both gases. The large temperature ranges for $\mathrm{H}_{2} \mathrm{O}\left(150-550^{\circ} \mathrm{C}\right)$ and $\mathrm{SO}_{2}\left(600-900^{\circ} \mathrm{C}\right)$ evolution suggest that the $\mathrm{H}_{2} \mathrm{O}$ is not loosely adsorbed on the hematite particles and that the $\mathrm{SO}_{4}$ is not structurally bonded, as loosely adsorbed water would be released at a lower temperature and structurally bonded $\mathrm{SO}_{4}$ would be evolved over a narrower temperature range. The "water" is likely present as $\mathrm{OH}^{-}$which replaces $\mathrm{O}^{=}$in the hematite structure, with the charge balance being maintained by vacancies in the $\mathrm{Fe}^{3+}$ sub-lattice. The IR spectrum shows vibrations at $\sim 3400 \mathrm{~cm}^{-1}$ and $\sim 1630 \mathrm{~cm}^{-1}$ that are consistent with $\mathrm{OH}^{-}$. Preliminary XPS analysis indicates that the $\mathrm{SO}_{4}$ is adsorbed on the $\mathrm{Fe}_{2} \mathrm{O}_{3}$ crystallites. 
A commercial hematite residue from Ruhr Zink consists of 3-40 $\mu \mathrm{m}$ sized $\mathrm{Fe}_{2} \mathrm{O}_{3}$ spheroids and trace amounts of $\mathrm{ZnFe}_{2} \mathrm{O}_{4}$ and jarosite. Detailed EPMA shows the hematite particles to contain $64.4 \% \mathrm{Fe}$,

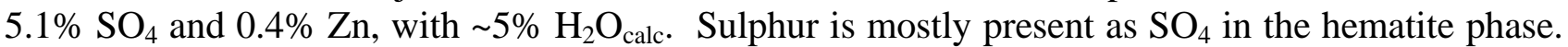
$\mathrm{X}$-ray mapping using crystal spectrometry shows that the distribution of $\mathrm{SO}_{4}, \mathrm{Zn}$ and $\mathrm{Fe}$ in the hematite particles is uniform down to the sub-micron level (Fig. 1). The FTIR curves are similar to those of the synthetic hematite precipitate. Approximately $6 \% \mathrm{H}_{2} \mathrm{O}$ is evolved between $100-550^{\circ} \mathrm{C}$, and 5-6 \% $\mathrm{SO}_{2}$ is released between $550-875^{\circ} \mathrm{C}$. The separate and large temperature ranges for $\mathrm{H}_{2} \mathrm{O}$ and $\mathrm{SO}_{2}$ evolution imply that the decomposition of $\mathrm{H}_{2} \mathrm{SO}_{4}$ is not the reaction involved. That is, the water is likely present as $\mathrm{OH}^{-}$. The hematite phase yields sharp XRD lines. The cell parameters of the hematite phase were calculated and correlated to the compositions. The $c$-parameter increases with increasing $\mathrm{Zn}$ content of the hematite phase, implying that the $\mathrm{Zn}$ is structurally bonded in the hematite phase and substitutes for Fe. No apparent correlation between the $\mathrm{SO}_{4}$ content and the cell parameters is observed, implying that the $\mathrm{SO}_{4}$ is not structurally bonded. The implication is that the $\mathrm{SO}_{4}$ is tenaciously adsorbed on the hematite particles. Several other commercial hematite precipitates were also studied, and the results are consistent with those reported above.

In conclusion, although the water and $\mathrm{SO}_{4}$ contents of the hematite precipitates can be eliminated by heating to $>800^{\circ} \mathrm{C}$, the $\mathrm{Zn}$ content persists because the $\mathrm{Zn}$ is structurally incorporated in the hematite. This means that the hematite precipitates currently produced in the zinc industry cannot be used for iron-making, unless a new technology can be developed to produce a more pure hematite residue. Although hematite is compact and is ideal for disposal, associated impurities presently require that the hematite residues be stored in controlled containment sites.

\section{References}

[1] J.E. Dutrizac, Acta Metallurgical Slovaca 2 (1996) 88-102.

[2] S. Seyer et al., JOM 53 (No.12) (2001) 32-35.

[3] L.I. Rosato and M.J. Agnew, in Iron Control and Disposal, J.E. Dutrizac and G.B. Harris, eds., CIM, Montreal, 1996, 77-89.

[4] T. Yamada et al., in Zinc and Lead Processing, J.E. Dutrizac et al., eds., CIM, Montreal, 1998, 627-638.
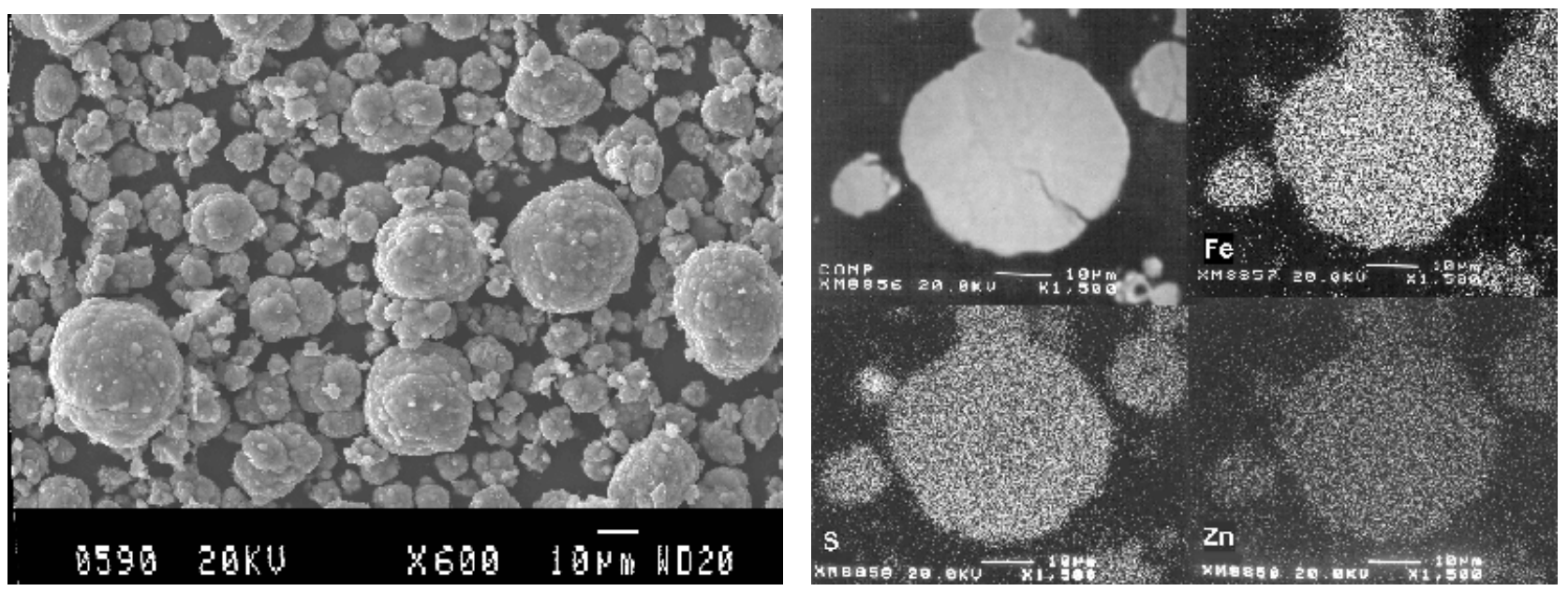

FIG. 1. Ruhr Zink hematite residue and the distributions of Fe, S and $\mathrm{Zn}$ in the hematite particles. 